\title{
EVALUASI INDEKS LUAS DAUN EMPAT GENOTIPE SORGUM (Sorghum bicolor [L.] Moench)
}

\section{EVALUATION OF LEAF AREA INDEX OF FOUR SORGHUM GENOTYPES (Sorghum bicolor [L.] Moench)}

\author{
Agsi Aji Ade Sadewo ${ }^{1}$, M. Syamsoel Hadi², Kukuh Setiawan ${ }^{3}$, Erwin Yuliadi ${ }^{4}$ \\ 'Mahasiswa Program Studi Agroteknologi, Fakultas Pertanian, Universitas Lampung \\ E-mail: agsiaji46@yahoo.com
}

Dikirim 7 Januari 2021, Direvisi 12 Maret 2021, Disetujui 5 April 2021

\begin{abstract}
Abstrak: Penelitian ini bertujuan mengevaluasi indeks luas daun empat genotipe sorgum (Sorghum bicolor [L.] Moench) dan menghitung pengaruh langsung dan tidak langsung beberapa variabel terhadap hasil produksi genotipe tanaman sorgum. Penelitian ini dilakukan di Laboratorium Lapang Terpadu, Universitas Lampung dari Januari hingga Juni 2019. Rancangan percobaan yaitu rancangan acak kelompok lengkap (RAKL) yang terdiri atas 4 perlakuan dengan 3 ulangan. Perlakuan yang digunakan empat genotipe sorgum seperti GH 13, GH 7, P/F 5-193-C, dan Super 2. Berdasarkan hasil penelitian, terdapat variasi karakter agronomi dari 4 genotipe tanaman sorgum. Variabel pengamatan yang berupa bobot dompolan (head) dan bobot dompolan (head) tanpa biji menjadi variabel penting untuk menduga hasil biji. Bobot dompolan (head) memiliki nilai korelasi sebesar $\mathrm{r}=0,99 * *$ dengan bobot biji. Selain itu, bobot dompolan (head) tanpa biji memiliki nilai korelasi sebesar $\mathrm{r}=0,84 * *$ dengan bobot biji. Bobot dompolan (head) juga memiliki nilai pengaruh langsung terhadap bobot biji terbesar dibandingkan dengan variabel lain yakni sebesar 1,205. Hal ini tidak diikuti dengan indeks luas daun yang tidak memiliki nilai korelasi yang nyata serta tidak memiliki pengaruh langsung dan tidak langsung terhadap bobot biji.
\end{abstract}

Kata kunci: Genotipe, indeks luas daun, karakter agronomi

\begin{abstract}
This experiment aimed to evaluate leaf area index of four sorghum genotypes (Sorghum bicolor [L.] Moench) and to calculate the direct and indirect effects of several variables on the yield of sorghum plant. This research was conducted in an Integrated Field Laboratory (LTPD), University of Lampung from January to June 2019. The experimental design was a completely randomized block design (CRBD) consisting of 4 treatments with 3 replications. The treatments used were four sorghum genotypes namely the GH 13, GH 7, P/F 5-193-C, and Super 2. The results showed there were variations in agronomic characters from 4 sorghum plant genotypes, variables head weight and head weight without seeds are important variables to estimate grain yield. The head weight with and without grain highly correlated with grain weight, $r=0,99 * *$ and $r=0,84 * *$ respectively. In addition, head weight had the highest direct influence on grain weight compared to other variables $(1,205)$. Meanwhile, leaf area index did not have a significant correlation with grain weight.
\end{abstract}

Keywords: Agronomic character, genotype, leaf area index

\section{PENDAHULUAN}

Sorgum merupakan tanaman serealia yang dapat tumbuh pada berbagai keadaan lingkungan, seperti tahan terhadap kekeringan sehingga potensi untuk dikembangkan, khususnya pada lahan marginal beriklim kering di Indonesia. Menurut Kementrian Pertanian (2018) luas lahan kering di Indonesia mencapai 16.954.030 hektar, sedangkan di provinsi lampung luas lahan kering 737.182 hektar. Sorgum sangat potensial untuk dikembangkan di lahan kering baik di
Indonesia maupun di Lampung, dengan keunggulan sorgum terletak pada daya adaptasi yang luas, toleran terhadap kekeringan, produktivitas tinggi, serta lebih tahan terhadap hama dan penyakit dibandingkan dengan tanaman pangan lainnya. Sorgum memiliki manfaat sebagai pakan ternak, bahan pangan, dan bahan industri (etanol), serta memiliki karakteristik tersendiri. Sorgum untuk kebutuhan pangan dan pakan sejak tahun 1970 diarahkan pada pemenuhan sumber karbohidrat, dengan mengharapkan bobot biji berat. Sorgum pangan dan pakan 
memiliki ciri umur genjah (70-80 hari), penampilan tanaman tidak terlalu tinggi $(100-140 \mathrm{~cm})$, kandungan protein di atas $10 \%$, dan kandungan tannin dibawah $0,2 \%$. Berdasarkan Penelitian Yusro (2001), menunjukkan semakin panjang umur berbunga dan umur masak serta jumlah daun semakin banyak maka tanaman semakin tinggi tetapi berkorelasi negatif terhadap bobot biji. Berdasarkan penelitian Aqil dkk. (2013) varietas sorgum tersebut memiliki umur genjah, tinggi tanaman yang pendek, dan bobot biji berat. Varietas yang dilepas adalah sorgum untuk kebutuhan pangan dan ditujukan untuk pemenuhan karbohidrat. Tanaman sorgum mempunyai pola pertumbuhan yang sama dengan jagung, namun interval waktu antara tahap pertumbuhan dan jumlah daun yang berkembang dapat berbeda. Waktu yang dibutuhkan untuk mencapai setiap tahap bergantung pada genotipe. Menurut Salisbury dan Ross (1995), pertumbuhan dan produksi tanaman sorgum dipengaruhi oleh pemilihan genotipe. Fase pertumbuhan sorgum seperti pembentukan daun akan mempengaruhi indeks luas daun. Indeks luas daun akan mempengaruhi laju fotosintesis yang menghasilkan fotosintat, jika mempengaruhi laju fotosintesis yang menghasilkan fotosintat, maka akan berdampak pada hasil produksi biji sorgum. Daun merupakan salah satu organ vegetatif yang sangat penting bagi tanaman sebagai tempat berlangsungnya fotosintesis, transpirasi tanaman, pertukaran udara, dan sebagai tempat regenerasi organ tanaman, serta menentukan indeks luas daun tanaman.

Oleh karena itu, jumlah daun pada tanaman yang optimum akan memberikan distribusi penerimaan cahaya yang merata. Distribusi penerimaan cahaya dapat diobservasi melalui pengamatan indeks luas daun (ILD). Indeks luas daun (Leaf Area Index/LAI) adalah salah satu parameter penting untuk mengidentifikasi produktivitas tanaman pertanian. Menurut Fakhrusy (2016) ILD didefiniskan sebagai nilai perbandingan antara total luas permukaan daun dengan total luas bidang tanah yang tertutupi oleh tajuk tanaman (kanopi). Nilai ILD memiliki nilai optimum, apabila terlalu tinggi maka akan berpengaruh terhadap kerapatan daun, dikarenakan pembentukan kanopi yang semakin lebat dan adanya efek saling menaungi, daun atas akan menutupi daun di bawahnya, sehingga daun terlindung tidak efektif berfotosintesis. Untuk mencapai pertumbuhan yang optimum maka laju asimilasi bersih juga harus optimum. Laju asimilasi bersih optimum juga digambarkan dengan nilai indeks luas daun yang optimum. Tanaman dengan nilai ILD yang optimum dapat dipastikan cahaya matahari diterima merata oleh daun tanaman. Salah satu indikasi bahwa nilai ILD optimum adalah cahaya matahari dapat masuk melalui kanopi tanaman. Cahaya yang masuk melalui kanopi tanaman akan mempengaruhi komponen vegetatif dan hasil setiap genotipe tanaman sorgum.

\section{METODOLOGI}

Penelitian ini dilakukan pada bulan Januari sampai dengan Mei 2019 pada lahan yang terletak di Laboratorium Lapang Terpadu, Kelurahan Gedong Meneng, Kecamatan Rajabasa, Kota Bandar Lampung. Bahan pada penelitian ini adalah dua genotipe sorgum yang sudah dirilis oleh pemerintah yaitu P/F-5-193-C dan Super 2 dan tiga genotipe sorgum yang belum dirilis oleh pemerintah yaitu $\mathrm{GH}$ (Galur Harapan) yang terdiri dari GH-13, dan GH-7. Pupuk yang digunakan yaitu pupuk Urea, TSP, dan $\mathrm{KCl}$. Alat yang digunakan dalam penelitian ini berupa alat pengolah tanah (cangkul), tali plastik, meteran, plang nama genotipe, bambu, label sampel, golok, gunting, cutter, ember, paranet, streples, timbangan elektrik, kertas koran, oven, seed blower, seed counter, alat tulis, kamera, SPAD-500, dan LAI-2200 plant canopy analyzer (PCA) (Li-Cor, Inc., Lincoln, Nebraska, U.S.A.). Empat genotipe sorgum (GH-13, GH-7, P/F-5- 
193-C, dan Super 2) disusun menggunakan Rancangan Acak Kelompok Lengkap (RAKL) dengan 3 ulangan. Jumlah seluruh satuan percobaan adalah 12 satuan percobaan. Pada setiap satu satuan percobaan diambil 5 tanaman yang akan digunakan sebagai sampel pengamatan. Homogenitas ragam diuji dengan uji Bartlett dan aditivitas data diuji dengan uji Tukey. Jika kedua asumsi terpenuhi, maka dilakukan analisis ragam yang dilanjutkan dengan uji BNT (beda nyata terkecil) pada taraf 5\% dengan menggunakan program Minitab (Versi 17). Untuk mengetahui hubungan antara dua karakter digunakan analisis korelasi dan dilanjutkan dengan analisis lintas. untuk mengetahui pengaruh langsung dan tidak langsung antara variabel $\mathrm{X}$ dengan variabel $\mathrm{Y}$.

Variabel yang diamati dalam penelitian ini meliputi komponen pertumbuhan (panjang batang, jumlah daun, kehijauan daun, diameter batang, indeks luas daun, jumlah ruas, bobot kering batang, bobot kering daun, dan bobot kering akar) dan komponen hasil (bobot dompolan/head, panjang malai, bobot dompolan/head tanpa biji, jumlah biji per tanaman, bobot biji per tanaman, dan bobot 1000 butir).

\section{HASIL DAN PEMBAHASAN}

Hasil penelitian menunjukkan genotipe sorgum terdapat variasi pada panjang batang 9 MST, panjang batang 17 MST, jumlah daun 17 MST, diameter batang 17 MST, jumlah ruas, bobot kering daun, bobot kering akar, panjang malai, bobot dompolan (head), bobot biji 1000 butir, bobot biji, dan jumlah biji. Hasil analisis ragam menunjukkan adanya variasi nyata pada beberapa variabel, dimana variabel ini dapat dilanjutkan untuk analisis selanjutnya, yaitu analisis BNT.
Tabel 1. Rekapitulasi hasil analisis ragam karakter agronomi empat genotipe sorgum

\begin{tabular}{lrrrrll}
\hline Variabel & Rataan & $\begin{array}{c}\text { KT } \\
\text { Genotipe }\end{array}$ & $\begin{array}{c}\text { KT } \\
\text { Kelompok }\end{array}$ & $\begin{array}{r}\text { KK } \\
(\%)\end{array}$ & $\begin{array}{l}\text { P-Value } \\
\text { Genotipe }\end{array}$ \\
\hline Komponen Pertumbuhan & & & & & \\
Panjang Batang 9 MST (cm) & 143,58 & $1506,80^{*}$ & 1031,10 & 13,33 & $0,011^{*}$ \\
Jumlah Daun 9 MST (helai) & 7,90 & 1,70 & $2,74^{*}$ & 11,14 & 0,099 \\
Kehijauan Daun 9 MST & 46,20 & 39,64 & 14,79 & 10,50 & 0,181 \\
Diameter Batang 9 MST (mm) & 10,67 & 17,84 & 36,80 & 24,38 & 0,299 \\
Indeks Luas Daun & 2,30 & 0,04 & 0,14 & 8,71 & 0,831 \\
Panjang Batang 17 MST (cm) & 228,90 & $9859,10^{* *}$ & $3946,60^{* *}$ & 10,90 & $0,000^{* *}$ \\
Jumlah Daun 17 MST (helai) & 8,18 & $3,84^{* *}$ & 0,02 & 11,15 & $0,006^{* *}$ \\
Diameter Batang 17 MST (mm) & 10,66 & $32,66^{* *}$ & 0,91 & 24,38 & $0,005^{* *}$ \\
Jumlah Ruas (ruas) & 7,81 & $14,33^{* *}$ & 1,25 & 14,46 & $0,000^{* *}$ \\
Bobot Kering Akar (g) & 15,72 & $261,45^{*}$ & 2,60 & 41,80 & $0,030^{*}$ \\
Bobot Kering Batang (g) & 65,43 & 1477,00 & 213,70 & 35,83 & 0,500 \\
Bobot Kering Daun (g) & 24,87 & $377,40^{*}$ & 322,40 & 41,04 & $0,019^{*}$ \\
Komponen Hasil & & & & & \\
Bobot Dompolan (head) (g) & 45,41 & $350,50^{*}$ & 137,90 & 41,24 & $0,012^{*}$ \\
Bobot Dompolan Tanpa Biji (g) & 11,54 & 31,24 & 0,06 & 48,60 & 0,250 \\
Bobot biji (g) & 34,10 & $203,10^{*}$ & 87,33 & 41,79 & $0,020^{*}$ \\
Panjang Malai (cm) & 18,03 & $25,36^{*}$ & 4,98 & 16,23 & $0,040^{*}$ \\
Bobot biji 1000 butir (g) & 25,60 & $46,69^{*}$ & 6,80 & 14,29 & $0,022^{*}$ \\
Jumlah Biji & 1228,70 & $293140^{*}$ & 2669,94 & 44,06 & $0,020^{*}$ \\
\hline
\end{tabular}

Keterangan : $*$ Nyata pada taraf 5\% $* *$ = Sangat nyata pada taraf $1 \%$

Dalam penelitian ini komponen hasil seperti bobot dompolan tanpa biji tidak berpengaruh nyata akan tetapi koefesien keragaman variabel tersebut menunjukkan lebih dari $20 \%$ sehingga keempat variabel ini memiliki keragaman yang tinggi dan dapat dijadikan kriteria seleksi (lebih dari 20\%) (Ahmad dkk., 2014).

\section{Komponen Pertumbuhan}

Komponen pertumbuhan menunjukkan bahwa genotipe berpengaruh nyata terhadap panjang batang sorgum pada 9 MST, panjang batang pada 17 MST, jumlah daun pada $17 \mathrm{MST}$, diameter batang pada 17 MST, jumlah ruas, bobot kering daun dan akar (Tabel 1). Variasi genotipe beberapa komponen pertumbuhan disajikan pada Tabel 2. 
Tabel

\section{Karakteristik komponen pertumbuhan empat genotipe sorgum}

\begin{tabular}{|c|c|c|c|c|c|c|c|c|c|}
\hline Genotipe & $\begin{array}{c}\text { Panjang } \\
\text { Batang } 9 \\
\text { MST }\end{array}$ & $\begin{array}{l}\text { Panjang } \\
\text { Batang } \\
17 \text { MST }\end{array}$ & $\begin{array}{c}\text { Jumlah } \\
\text { Daun } 9 \\
\text { MST }\end{array}$ & $\begin{array}{c}\text { Jumlah } \\
\text { Daun } 17 \\
\text { MST }\end{array}$ & $\begin{array}{c}\text { Kehijauan } \\
\text { Daun }\end{array}$ & $\begin{array}{l}\text { Jumlah } \\
\text { Ruas }\end{array}$ & $\begin{array}{l}\text { Diameter } \\
\text { Batang } \\
\text { 9MST }\end{array}$ & $\begin{array}{c}\text { Diameter } \\
\text { Batang } 17 \\
\text { MST }\end{array}$ & $\begin{array}{l}\text { Jumlah } \\
\text { notasi a }\end{array}$ \\
\hline & \multicolumn{2}{|c|}{................... } & \multicolumn{2}{|c|}{........helai......... } & & \multicolumn{4}{|c|}{$\ldots \ldots \ldots . . m m \ldots$} \\
\hline GH-13 & $135,03 \mathrm{~b}$ & $191,27 \mathrm{~b}$ & 8,13 ab & $7,76 \mathrm{~b}$ & $48,22 \mathrm{a}$ & $6,46 \mathrm{c}$ & 9,35 a & 10,87 ab & 4 \\
\hline GH-7 & $157,33 \mathrm{a}$ & 237,50 a & $8,23 \mathrm{a}$ & $8,16 \mathrm{~b}$ & $46,57 \mathrm{a}$ & $7,80 \mathrm{~b}$ & 11,95 a & $9,95 \mathrm{~b}$ & 5 \\
\hline $\mathrm{P} / \mathrm{F}-5-193 \mathrm{C}$ & $137,40 \mathrm{~b}$ & 237,93 a & 7,70 ab & $8,90 \mathrm{a}$ & 44,41 a & 8,73 a & 10,40 a & $9,21 \mathrm{~b}$ & 6 \\
\hline Super 2 & $144,56 \mathrm{ab}$ & 248,90 a & $7,53 \mathrm{~b}$ & $7,90 \mathrm{~b}$ & $45,50 \mathrm{a}$ & 8,26 ab & 10,98 a & 12,63 a & 6 \\
\hline $\mathrm{BNT}_{(0,15)}$ & 14,01 & 18,27 & 0,64 & 0,67 & 3,24 & 0,83 & 2,76 & 1,90 & \\
\hline
\end{tabular}

Keterangan : Angka yang diikuti huruf yang sama pada kolom yang menunjukkan tidak berbeda nyata berdasarkan uji BNT $5 \%$.

Dalam penelitian ini terdapat variasi panjang batang pada saat 9 MST (Tabel 2). Genotipe GH-7 menjadi yang terpanjang pada saat $9 \mathrm{MST}$. Akan tetapi pada $17 \mathrm{MST}$ genotipe P/F-5-193-C, Super 2, dan GH-7 menjadi genotipe terpanjang pada saat panen, sedangkan genotipe GH-13 menjadi genotipe terpendek saat panen.

Hasil penelitian menunjukkan bahwa secara umum pada fase pertumbuhan, panjang batang dan jumlah daun mengalami peningkatan sejak 6 MST hingga 9 MST untuk semua genotipe tanaman sorgum (Gambar 1 dan 2).

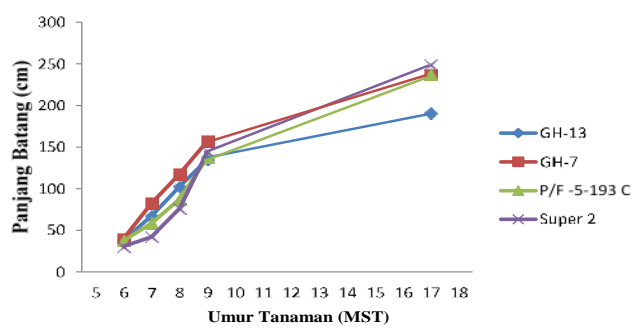

Gambar1. Pertumbuhan panjang batang empat genotipe sorgum.

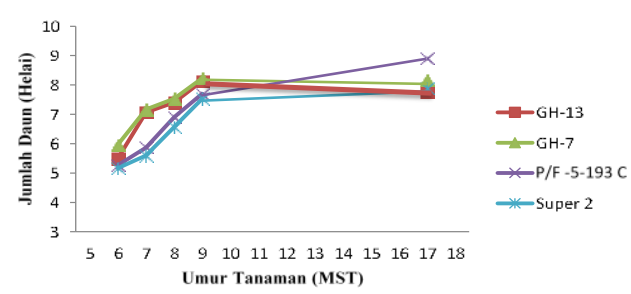

Gambar 2. Pertumbuhan jumlah daun empat genotipe sorgum.
Panjang batang maupun jumlah daun meningkat pada $6,7,8$, dan 9 MST tanaman sorgum berada pada fase vegetatif dimana bagian tanaman sedang aktif berkembang (bagian daun dan tunas) sehingga terjadi pertumbuhan cepat (Vanderlip, 1993). Hasil penelitian ini sesuai dengan penelitian yang dilakukan Siregar dkk. (2016), tanaman sorgum pada fase pertumbuhan $(5,6,7$, dan 8 MST) memiliki tinggi dan jumlah daun yang terus bertambah setiap minggunya. Pertumbuhan tinggi Super 2 setelah 9 MST sangat pesat, dan melebihi GH-7. Hal ini terjadi kemungkinan genotipe GH-7 mengalami pertumbuhan cepat pada $6,7,8$, dan 9 MST (Vanderlip,1993), sedangkan genotype Super 2 kemungkinan pertumbuhan tinggi tanaman tetap berjalan hingga menjelang panen. Munculnya daun bendera bukan menjadi fase vegetatif yang terakhir dalam penambahan panjang batang, hal ini dibuktikan dalam penelitian ini yang menunjukkan pertumbuhan panjang batang terjadi hingga menjelang panen (Gambar 1). Variasi dan penambahan panjang batang hingga menjelang panen tidak hanya terjadi dalam penelitian ini, pada penelitian Yanuar (2018) yang terdapat variasi pada tinggi tanaman, genotipe P/F-5-193-C menjadi genotipe tertinggi yang ditanam bersamaan dengan genotipe GH-7, Super 2, dan GH-13. Pertumbuhan semua genotipe dalam penelitian Yanuar (2018) terjadi hingga saat menjelang panen. Dalam penelitian ini terdapat variasi jumlah daun pada saat 9 MST dan 17 MST. Akan tetapi, terdapat beberapa genotipe sorgum yang menurun jumlah daunnya dari 9 hingga 17 MST. Hal ini terjadi, karena terdapat daun yang sudah tua dan lepas dari batang tanaman, sedangkan tanaman sudah mulai memasuki fase generatif sehingga tidak terjadi lagi penambahan daun. Penurunan jumlah daun yang terjadi pada tanaman sorgum terjadi pada tanaman jagung yang diteliti oleh Tira (2018), penurunan jumlah daun pada tanaman jagung terjadi karena adanya penuaan daun. 
Karakteristik tinggi tanaman dan jumlah daun dipengaruhi oleh faktor genetik hal ini didukung oleh Salisbury dan Ross (1995), yang menyatakan karakteristik agronomi tanaman seperti tinggi tanaman, diameter batang, bobot brangkasan, bobot biji dan lain-lain dipengaruhi oleh faktor genetik. Faktor genetik tidak hanya mempengaruhi variasi pada tinggi tanaman dan jumlah daun saja. Akan tetapi dalam penelitian ini dan penelitian Yanuar (2018) variabel jumlah ruas terdapat variasi. Dalam penelitian ini panjang malai pada saat panen terdapat variasi, dengan genotipe GH-7 menjadi genotipe terpanjang. Akan tetapi, pada penelitian Yanuar (2018) genotipe GH-13 memiliki panjang malai yang lebih dibandingkan dengan GH-7. Hasil yang bertentangan ini dikarenakan perbedaan lingkungan, hal ini didukung dengan pernyataan Salisbury dan Ross (1995), menyatakan tanaman dengan genotipe yang sama dapat memiliki penampilan yang berbeda jika ditanam pada lingkungan yang berbeda. Kehijauan daun pada penelitian ini tidak berbeda nyata antargenotipe tanaman sorgum. Menurut penelitian yang dilakukan Siregar dkk. (2016), kehijauan daun varietas Kawali, Numbu, Super 2 tidak berbeda nyata antargenotipenya karena diduga disebabkan oleh faktor genetik tanaman sorgum. Kemungkinan gen yang mengatur kehijauan daun pada beberapa genotipe tanaman sorgum tersebut sama-sama membentuk klorofil dalam jumlah yang tidak berbeda sehingga diperoleh hasil bahwa kehijaun daun antargenotipe tidak berbeda nyata.

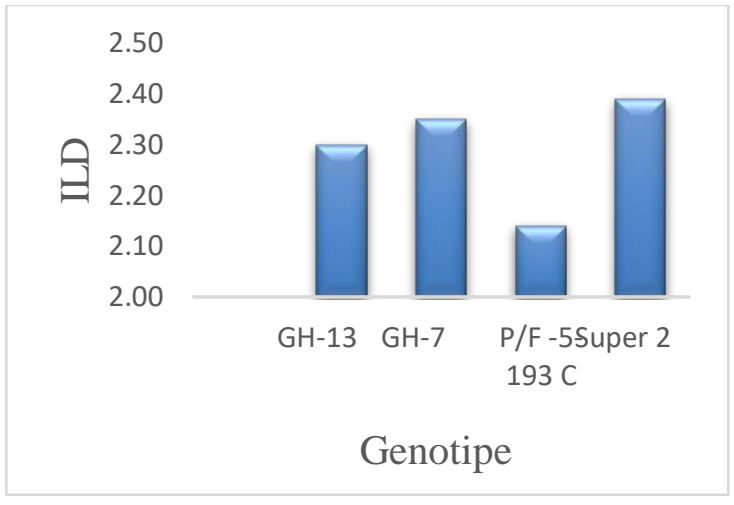

Gambar 3. Indeks luas daun empat genotipe sorgum.

Indeks luas daun (ILD) dalam penelitian ini tidak terdapat variasi serta diukur saat daun bendera muncul (9 MST). Akan tetapi, berdasarkan Gambar 3 genotipe super 2 relatif lebih tinggi $(2,39)$ dibandingkan dengan genotipe lainnya. ILD dalam penelitian ini tidak terdapat variasi kemungkinan karena hanya diukur satu waktu saja (9 MST) karena, fase pertumbuhan awal dan saat panen

kemungkinan nilai ILD berbeda jika diukur. Nilai ILD saat daun bendera muncul dengan saat panen kemungkinan berbeda karena dalam penelitian ini dan Yanuar (2018) saat daun bendera muncul bukan menjadi fase vegetatif yang terakhir dalam penambahan panjang batang. Penambahan panjang batang terjadi hingga menjelang panen (Gambar 3).

ILD merupakan ukuran kasar luas daun per satuan radiasi matahari yang tersedia, Artinya, ILD adalah total area daun yang akan digunakan untuk penyerapan radiasi matahari pada proses fotosintesis yang akan menghasilkan fotosintat dan berdampak pula pada bobot kering tanaman sorgum. Hal ini didukung oleh pernyataan Harjadi (1991) Produksi fotosintat yang lebih besar akan memungkinkan membentuk seluruh organ tanaman yang lebih besar seperti daun dan akar yang kemudian menghasilkan produksi bahan kering yang semakin besar. Dalam penelitian ini genotipe Super 2 memiliki nilai ILD yang 
relatif tinggi dibandingkan dengan genotipe lainnya dan selaras dengan hasil fotosintat dalam hal ini adalah brangkasan genotipe Super 2 lebih tinggi dibandingkan dengan genotipe lainnya berdasarkan pemisahan nilai tengah yang akan disajikan pada Tabel 3.

Tabel 3. Karakteristik komponen pertumbuhan (brangkasan) empat genotipe sorgum

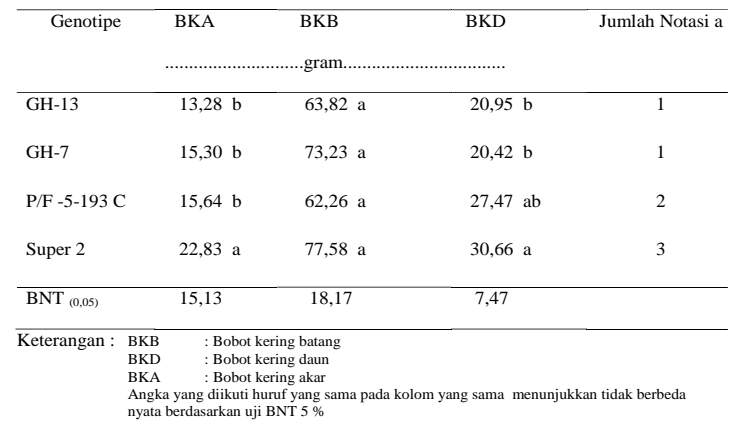

Genotipe Super 2 memiliki nilai notasi A terbanyak dalam hal bobot brangkasan dibandingkan dengan genotipe lainnya. Artinya, bobot brangkasan genotipe Super 2 menjadi yang terberat dalam penelitian ini. Bobot brangkasan genotipe Super 2 menjadi yang terberat didukung pula oleh nilai ILD yang tinggi pula pada genotipe Super 2. Hal ini didukung oleh pernyataan Harjadi (1991) Produksi fotosintat yang lebih besar akan memungkinkan membentuk seluruh organ tanaman yang lebih besar seperti daun dan akar yang kemudian menghasilkan produksi bahan kering yang semakin besar.

Dalam penelitian ini genotipe Super 2 memiliki bobot brangkasan yang berat dibandingkan genotipe GH 13. Hal ini terjadi karena translokasi fotosintat ke batang, akar, dan daun lebih banyak. Hadi dkk. (2016), menjelaskan meningkatnya bobot kering batang justru akan menurunkan translokasi fotosintat ke biji. Yu dkk. (2015) menjelaskan lemahnya kekuatan wadah (bobot biji), menyebabkan terjadinya akumulasi karbohidrat di organ sumber (brangkasan).

Karakter agronomi lain yang terdapat variasi adalah bobot kering daun. Genotipe Super 2 memiliki bobot kering daun terberat $(30,66$ gram $)$ diikuti genotipe P/F-5-193-C (27,47 gram), sedangkan genoipe GH-13 dan GH-7 tidak berbeda nyata. Daun merupakan bagian tanaman tempat terjadinya fotosintesis. Artinya, semakin lebar dan panjang daun maka bobot tanaman akan semakin meningkat. Hal ini dibuktikan dalam penelitian Nasution (2010), yang terdapat korelasi antara lebar daun dengan bobot tanaman $\left(\mathrm{r}=0,51^{*}\right)$ dan panjang daun dengan bobot tanaman $\left(\mathrm{r}=0,52^{* *}\right)$. Daun berperan penting dalam proses terbentuknya fotosintat. Hasil fotosintat tersebut berperan penting juga dalam peningkatan bobot

kering akar. Pertumbuhan akar yang baik akan berperan penting pada pertumbuhan batang dan daun.

\section{Komponen Hasil}

Komponen hasil menunjukkan bobot dompolan (head), bobot dompolan tanpa biji, bobot biji, jumlah biji, dan panjang malai terdapat variasi yang akan disajikan pada Tabel 4.

Tabel 4. Karakteristik beberapa komponen hasil beberapa genotipe tanaman sorgum pada saat panen.

\begin{tabular}{|c|c|c|c|c|c|c|c|}
\hline Genotipe & BD & BDTB & BB & JB & BB 1000 & PM & $\begin{array}{c}\mathrm{Jml} \\
\text { Notasi a }\end{array}$ \\
\hline GH-13 & $51,10 \mathrm{a}$ & $12,24 \mathrm{ab}$ & $38,40 \mathrm{a}$ & $1268,07 \mathrm{ab}$ & $27,19 \mathrm{a}$ & $18,33 \mathrm{ab}$ & 6 \\
\hline GH-7 & 52,78 a & 13,91 a & 39,27 a & 1559,20 a & $24,37 \mathrm{~b}$ & 19,57 a & 5 \\
\hline $\mathrm{P} / \mathrm{F}-5-193 \mathrm{C}$ & $32,14 \mathrm{~b}$ & $8,62 \mathrm{~b}$ & $24,18 \mathrm{~b}$ & $909,40 \mathrm{~b}$ & $23,83 \mathrm{~b}$ & $16,43 \mathrm{~b}$ & 0 \\
\hline Super 2 & $45,46 \mathrm{ab}$ & $11,01 \mathrm{ab}$ & $34,44 \mathrm{ab}$ & $1178,00 \mathrm{ab}$ & 27,07 a & $17,77 \mathrm{ab}$ & 6 \\
\hline BNT $_{(0,05)}$ & 13,43 & 4,48 & 10,18 & 761,61 & 2,67 & 2,14 & \\
\hline Keterangan: & $\begin{array}{l:}\text { PM } \\
\text { BD } \\
\text { BDTB } \\
\text { BB } \\
\text { B100 } \\
\text { JB } \\
\text { Angka yang } \\
\text { tidak berbed }\end{array}$ & $\begin{array}{l}\text { Panjang M } \\
\text { Bobot Don } \\
\text { Bobot Don } \\
\text { Bobot Biji } \\
\text { Bobot } 100 \\
\text { Jumlah Bij } \\
\text { diikuti hur } \\
\text { la nyata ber }\end{array}$ & $\begin{array}{l}\text { lai } \\
\text { polan }(\mathrm{Hec} \\
\text { polan }(\mathrm{Hec} \\
\text { Butir } \\
\text { f yang sam }\end{array}$ & $\begin{array}{l}\text { d) } \\
\text { d) Tanpa Biji } \\
\text { a pada kolom y } \\
\text { BNT } 5 \%\end{array}$ & ing sam & enun & \\
\hline
\end{tabular}


Dalam penelitian ini salah satu komponen hasil yang memiliki variasi adalah komponen bobot biji 1000 butir. Variasi pada bobot biji 1000 butir terjadi karena perbedaan ukuran diameter biji. Ukuran biji akan berdampak pada bobot biji tentunya. Akan tetapi, dalam penelitian ini tidak dilakukan pengukuran diameter biji tanaman. Genotipe GH 13 dan Super 2 menjadi yang terberat berdasarkan jumlah notasi. Berdasarkan penelitian Yanuar (2018), menyatakan genotipe GH 13 merupakan genotipe yang berpotensi sebagai genotipe penghasil biji karena genotipe tersebut memiliki bobot biji lebih tinggi dibandingkan dengan genotipe lainnya. Genotipe dengan bobot biji yang tinggi memiliki karakteristik tinggi tanaman, bobot kering batang, daun, dan akar yang lebih rendah (Hadi dkk., 2016). Hal ini sejalan dengan penelitian ini, genotipe $\mathrm{GH} 13$ memiliki karakteristik tinggi tanaman, bobot kering batang, daun, dan akar yang rendah (kecuali bobot kering akar tidak memiliki vaariasi) berdasarkan uji beda nyata terkecil.

Pengamatan pada bobot dompolan sorgum (Tabel 4) menunjukkan bahwa genotipe terdapat variasi. Genotipe GH-13 (51,10 g) dan GH-7 (52,78 g) memiliki bobot dompolan terberat dibandingkan dengan genotipe lainnya. Genotipe P/F-5-193-C $(32,14 \mathrm{~g})$ menjadi genotipe dengan bobot domopolan teringan. Bobot biji pada Tabel 4 terdapat variasi. Genotipe GH-13 $(38,40$ g) dan GH-7 (39,27 g) memiliki bobot biji terberat dibandingkan dengan genotipe lainnya. Genotipe P/F-5-193-C (24,18 g) menjadi genotipe dengan bobot biji teringan. Berat ringannya bobot dompolan dan bobot biji diduga akibat perbedaan bobot dompolan tanpa biji yang memiliki variasi juga (Tabel 4). Genotipe GH-7 $(13,91 \mathrm{~g})$ memiliki bobot dompolan tanpa biji terberat dibandingkan dengan genotipe lainnya, diikuti Genotipe GH-13 (12,24 g). Genotipe P/F-5-193-C (32,14 g) menjadi genotipe dengan bobot domopolan teringan. Hubungan bobot dompolan dan bobot biji dengan bobot bobot dompolan tanpa biji (bobot malai) didukung dengan hasil analisis korelasi antara bobot dompolan dengan bobot dompolan tanpa biji ( $r=$ $\left.0,91^{* *}\right)$ yang berkorelasi sangat nyata positif, serta hasil analisis korelasi antara bobot biji dengan bobot dompolan tanpa biji $\left(\mathrm{r}=0,84^{* *}\right)$ berkorelasi sangat nyata positif. Hasil analisis korelasi akan disajikan dalam Tabel 5.

Tabel 5. Koefesien korelasi beberapa variabel pertumbuhan dan hasil empat genotipe sorgum.

\begin{tabular}{|c|c|c|c|c|c|c|c|c|c|c|c|c|}
\hline Variabel & BB & KDOMST & LD T T & TTIMNST & JDITMST & DB177NST & BDH & ВमПтв & BB1000Bubur & $\mathrm{BKA}$ & BKB & BKD \\
\hline BB & & 0.55 & 0,09 & 0,18 & 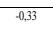 & 0,40 & $0.99^{98}$ & $0,84^{* *}$ & 0,13 & 0,33 & $0,61^{8}$ & 0,15 \\
\hline KD९MST & 0,06 & & 0,12 & $-0,43$ & $-0,12$ & $0.0,04$ & $0,57^{*}$ & 0,57 & 0,08 & $-0,29$ & 0,15 & -0,19 \\
\hline II.D & 0,78 & 0,72 & & $-0,28$ & $-0,02$ & $.0,05$ & $-0,02$ & 0,19 & $-0,26$ & $-0,45$ & -0,52 & $-0,12$ \\
\hline TIIMST & 0.57 & 0,17 & 0,38 & & 0,08 & 0.33 & 0,15 & 0,10 & $-0,15$ & $0,67^{*}$ & $0.58^{x}$ & 0.39 \\
\hline JDITMST & 0,30 & 0,72 & 0,96 & 0,81 & & $-0.76^{* *}$ & $-0,36$ & .0,32 & 0,01 & $-0,33$ & -0,20 & 0,03 \\
\hline DBIIMST & 0.20 & 0.91 & 0,87 & 0,30 & 0,00 & & 0,41 & 0,34 & 0.24 & $0,77^{58}$ & 0.54 & 0.46 \\
\hline BDH & 0,00 & 0.05 & 0,96 & 0.65 & 0.26 & 0,19 & & $0.91^{1 * *}$ & 0,06 & 0.29 & 0.54 & 0,13 \\
\hline BमfTB & 0,00 & 0,06 & 0,56 & 0.76 & 0,31 & 0.28 & 0,00 & & $-0,17$ & 0,14 & 0,34 & 0,07 \\
\hline 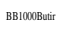 & 0,70 & 0,81 & 0,41 & 0.64 & 0.97 & 0.45 & 0.86 & 0.59 & & 0.36 & 0.35 & 0,11 \\
\hline BKA & 0.29 & 0,37 & 0,14 & 0,02 & 0,30 & 0,01 & 0,36 & 0,67 & 0,25 & & $0,70^{* * *}$ & $0,59^{\circ}$ \\
\hline вКв & 0,04 & 0.63 & 0,08 & 0.05 & 0,53 & 0.07 & 0,07 & 0,29 & 0.26 & 0,01 & & 0,48 \\
\hline BKD & 0.64 & 0.57 & 0.77 & 0.21 & 0.94 & 0.13 & 0.69 & 0.82 & 0.73 & 0.05 & 0.12 & \\
\hline
\end{tabular}

Keterangan :

Angka di atas garis diagonal adalah nilai korelasi, sedangkan angka di bawah garis diagonal adalah menunjukkan peluang adanya korelasi $*$ : Nyata pada $\alpha \leq 0,05$; $* *$ : Nyata pada $\alpha \leq 0,01$; BBFMF: Bobot Biji ; KD9MT: Kehijauan Daun 9 Minggu Setelah Tanaman ; ILD: Indeks Luas Daun ; TT17MST: Tinggi Tanaman 17 Minggu Setelah Tanam ; JD17MST: Jumlah Daun 17 Minggu Setelah Tanam; DB17MST: Diameter Batang 17 Minggu Setelah Tanam ; BDH: Bobot Dompolan (Head) ; BDHTB: Bobot Dompolan (Head) Tanpa Biji; BB1000Butir: Bobot Biji 1000 Butir ; BKA: Bobot Kering Akar; BKB: Bobot Kering Batang; BKD: Bobot Kering Daun. Hasil analisis korelasi menunjukkan terdapat korelasi yang tinggi antara bobot biji dan bobot dompolan (head) yang dihasilkan tanaman sorgum ( $\mathrm{r}=0,99 * *)$.

Hal ini didukung oleh analisis sidik lintas dengan pengaruh langsung yang mencapai 1,205. Hasil penelitian menunjukkan bahwa bobot biji yang dihasilkan tanaman sorgum berkorelasi nyata positif dengan bobot dompolan (head) tanpa biji dan bobot 
kering batang. Bobot dompolan (head) tanpa biji memiliki nilai korelasi dengan bobot biji sebesar $\left(\mathrm{r}=0,84^{* *}\right)$, sedangkan bobot kering batang memiliki nilai korelasi degan bobot biji sebesar $\left(\mathrm{r}=0,61^{*}\right)$.

Bobot dompolan (head) tanpa biji memiliki nilai korelasi yang tinggi tehadap bobot biji $\left(\mathrm{r}=0,84^{* *}\right)$. Hal ini terjadi karena, bobot dompolan tanpa biji (malai) yang besar akan mempengaruhi biji sorgum yang akan muncul, seperti yang kita ketahui malai adalah letak biji sorgum yang akan muncul. Pernyataan ini sesuai dengan Andriani dan Isnaini (2006), produksi biji dipengaruhi oleh pertumbuhan malai tanaman sorgum karena jumlah biji yang akan diproduksi maksimum $70 \%$ dari total bakal biji yang tumbuh.

Hasil penelitian menunjukkan bahwa bobot biji berkorelasi tinggi dengan bobot dompolan (head) dan bobot dompolan (head) tanpa biji, maka variabel tersebut merupakan fokus utama dalam pemilihan genotipe sorgum penghasil biji. Berdasarkan hasil analisis korelasi dalam penelitian ini, bobot biji tinggi didukung bobot dompolan (head) tanpa biji yang tinggi pula. Akan tetapi dalam analisis lintas bobot dompolan (head) tanpa biji memiliki nilai pengaruh langsung sangat kecil $\quad(-0,269)$ hal ini tidak sejalan dengan pernyataan analisis korelasi yang menyatakan bahwa bobot dompolan (head) tanpa biji memiliki nilai korelasi yang besar. Hal ini bisa terjadi karena, dalam salah satu sampel tanaman memiliki kemungkinan terjadinya bobot dompolan (head) tanpa biji yang besar akan tetapi memiliki bobot biji yang kecil.

ILD bisa dijadikan variabel untuk mengukur fotosintat yang dihasilkan. Watson (1947) mendefinisikan ILD sebagai dimensi variabel sebagai interpretasi luasan total area fotosintesis per luasan area permukaan tanah. Total luasan area fotosintesis akan mempengaruhi penyerapan radiasi matahari pada proses fotosintesis yang akan menghasilkan fotosintat. Akan tetapi dalam analisis korelasi yang telah dilakukan dalam penelitian ini tidak terdapat nilai korelasi yang nyata antara ILD dengan komponen pertumbuhan maupun hasil. Akan tetapi dalam penelitian Arunah dkk. (2015), terdapat korelasi antara LAI dengan panjang batang, bobot malai, panjang malai, dan bobot biji 1000 butir. Perbedaan ini terjadi karena perbedaan perlakuan kedua penelitian ini seperti, perlakuan pupuk urea, pupuk kandang, hingga jumlah genotipe yang ditanam dalam penelitian Arunah et al. Berjumlah 2 berbeda dengan penelitian ini yang menggunakan 4 genotipe perlakuan tanpa perlakuan yang lain.

Pertumbuhan daun yang baik akan sangat membantu dalam meningkatkan biomassa akar. Pertumbuhan akar yang baik akan berdampak pada peningkatan bobot kering batang. Hubungan antara bobot kering akar dengan bobot kering batang diuji dalam analisis korelasi $(\mathrm{r}=0,70 * *)$. Semakin berat bobot kering akar maka bobot kering batang akan semakin berat pula, semakin baik pertumbuhan akar maka akan meningkatkan biomassa batang. Hal ini didukung oleh pernyataan Hadi dkk. (2016) Akar berperan penting dalam peningkatan bobot kering batang dan daun. Dalam penelitian Hadi dkk. (2016) GH-10 memiliki bobot kering akar terberat $(20,88$ g) dan diikuti pula bobot kering batang yang berat $(134,00 \mathrm{~g})$. Pertumbuhan akar yang baik akan sangat membantu dalam meningkatkan biomassa tajuk, yaitu batang dan daun, dalam rangka menghasilkan hijauan ternak. Bobot kering batang yang berat menandakan batang tersebut tinggi, hal ini dibuktikan dengan adanya analisis korelasi antara bobot kering batang dengan tinggi tanaman $\left(\mathrm{r}=0,58^{*}\right)$. Akan tetapi tidak hanya batang saja yang menjulang tinggi, bobot biji mengalami peningkatan seiring dengan meningkatnya

bobot kering batang. Pernyataan tersebut didukung dengan adanya analisis korelasi antara bobot kering batang dengan bobot biji $\left(\mathrm{r}=0,61^{*}\right)$. Dalam analisis korelasi 
tinggi tanaman tidak terdapat korelasi dengan bobot biji, akan tetapi dalam analisis sidik lintas tinggi tanaman memiliki pengaruh langsung positif $(0,075)$ dengan bobot biji. Tabel analisis lintas akan disajikan pada Tabel 6.

Tabel 6. Pengaruh langsung dan tidak langsung variabel indeks luas daun terhadap hasil/bobot biji beberapa genotipe sorgum.

\begin{tabular}{|c|c|c|c|c|c|c|c|c|c|c|c|}
\hline VARIABEL & KDOMST & ILD & TIITMST & JDI7WST & DBITMST & BDH & вонтв & BBIOOOBüur & BKA & вКв & BKD \\
\hline KDOMST & 0,031 & $0,0,044$ & $-0,013$ & $0,0,044$ & $-0,001$ & 0,018 & 0,018 & 0,002 & $0.0,099$ & 0,005 & $-0,006$ \\
\hline แLD & -0,001 & $-0,005$ & 0,001 & 0,000 & 0,000 & 0,0000 & -0,001 & 0,001 & 0,002 & 0,003 & 0,001 \\
\hline TTIIMST & -0,032 & $-0,021$ & 0,775 & $0,0,066$ & 0,025 & 0,011 & 0.007 & $-0,011$ & 0.050 & 0,043 & 0,029 \\
\hline JDITMST & 0,002 & 0,000 & $-0,001$ & $-0,014$ & 0,011 & 0,005 & 0,005 & 0,000 & 0.005 & 0,003 & 0,000 \\
\hline DBITMST & 0,001 & 0,001 & $-1,0,077$ & 0,017 & $-1,023$ & -1,0,099 & $0,0,008$ & $-0,066$ & .0,017 & $-0,012$ & $-0,011$ \\
\hline BDH & 0,6855 & $\cdot 0,020$ & 0,175 & $-0,430$ & 0,490 & 1,2015 & 1,091 & 0,068 & 0.354 & 0.647 & 0,158 \\
\hline BDHTB & $-0,153$ & $-0,050$ & $-0,066$ & $0,0,866$ & $-0,991$ & $-1,244$ & . & 0,046 & -0,037 & 0,090 & $-0,020$ \\
\hline BBDIOOBButir & 0,003 & $.0,009$ & $-0,005$ & 0,0000 & 0,008 & 0,002 & $.0,006$ & 0,034 & 0,012 & $0,0,12$ & 0,004 \\
\hline BKA & 0.016 & 0,025 & $-0,0,37$ & 0,018 & -0.042 & -1,016 & $.0,008$ & $-0,020$ & $-0,056$ & $-0,039$ & $-0,033$ \\
\hline BKB & 0,005 & $0.0,15$ & 0.017 & $-0,006$ & 0,016 & 0,016 & 0,010 & 0,010 & 0,021 & $0,0,30$ & 0,014 \\
\hline BKD & -0,0013 & 0.002 & 0,006 & 0,000 & 0,007 & 0,002 & 0,001 & 0,002 & 0,009 & 0,007 & 0,015 \\
\hline $\begin{array}{l}\text { TOTAL } \\
\end{array}$ & 0,554 & $0.0,992$ & 0,184 & 0.0326 & 0,0400 & 0,990 & 0,840 & 0,127 & 0,333 & 0,607 & 0,152 \\
\hline
\end{tabular}

Keterangan :

Angka bercetak tebal adalah nilai pengaruh langsung variabel pengamatan terhadap hasil/bobot biji ; KD9MT: Kehijauan Daun 9 Minggu Setelah Tanaman ; ILD: Indeks Luas Daun ; TT17MST: Tinggi Tanaman 17 Minggu Setelah Tanam ; JD17MST: Jumlah Daun 17 Minggu Setelah Tanam; DB17MST: Diameter Batang 17 Minggu Setelah Tanam ; BDH: Bobot Dompolan (Head) ; BDHTB: Bobot DompolanHead) Tanpa Biji; BB1000Butir: Bobot Biji 1000 Butir ; BKA: Bobot Kering Akar; BKB: Bobot Kering Batang; BKD: Bobot Kering Daun.

Dalam analisis sidik lintas yang dilakukan, bobot kering akar memiliki nilai pengaruh tidak langsung $(0,354)$ terhadap bobot biji melalui bobot dompolan (head) lebih kecil dibandingkan dengan pengaruh tidak langsung bobot kering batang $(0,647)$ terhadap bobot biji melalui bobot dompolan (head). Seharusnya nilai pengaruh tidak langsung bobot kering akar lebih besar dibandingkan dengan bobot kering batang, karena seperti yang kita tahu akar memiliki fungsi vital dalam tanaman seperti menyerap air dan unsur hara di dalam tanah.
Semakin baik pertumbuhan akar maka pertumbuhan batang, daun, dan biji menjadi baik pula. Hal ini didukung oleh pernyataan Hadi dkk. (2016) Akar berperan penting dalam peningkatan bobot kering batang dan daun. Kenapa pengaruh tidak langsung bobot kering akar lebih besar dibandingkan dengan bobot kering batang, hal ini terjadi kemungkinan dalam pelaksanaan pengambilan akar masih terdapat akar yang tertinggal di lahan pertanian, sehingga menyebabkan nilai pengaruh tidak langsung bobot kering akar terhadap bobot biji lebih kecil dibandingkan dengan bobot kering akar. Seharusnya, jika ingin mengamati bobot kering akar sebaiknya menggunakan polybag sehingga meminimumkan kehilangan akar tanaman. Nilai pengaruh tidak langsung bobot kering akar dan bobot kering batang terhadap bobot biji melalui bobot dompolan akan diuraikan pada Gambar 4.

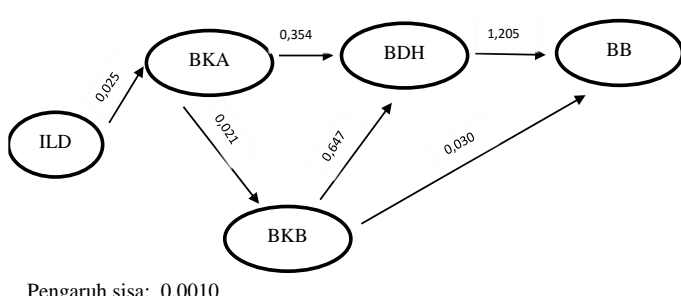

Pengaruh sisa: 0,0010

Gambar 4. Diagram pengaruh langsung dan tidak langsung variabel indeks luas daun terhadap bobot biji sorgum.

Keterangan: ILD: Indeks Luas Daun ; BDH: Bobot Domolan (Head) ; BKB: Bobot Kering Batang ; BB: Bobot Biji ; BKA: Bobot Kering Akar.

Pada Gambar 5 dapat dilihat indeks luas daun memiliki pengaruh tidak langsung terhadap bobot biji melalui bobot kering akar $(0,025)$. Sedangkan bobot kering akar memiiki pengaruh tidak langsung terhadap bobot biji melalui bobot kering batang sebesar $(0,021)$, pengaruh langsung bobot kering batang terhadap bobot biji nilainya $(0,030)$. Bobot kering akar juga memiliki pengaruh tidak langsung terhadap bobot biji 
melalui bobot dompolan (head) sebesar $(0,354)$.

Bobot kering batang ternyata memiliki pengaruh tidak langsung terhadap biji lebih besar dibadingkan dengan bobot kering akar. Pengaruh tidak langsung bobot kering batang terhadap bobot biji melalui bobot dompolan (head) sebesar $(0,647)$. Bobot dompolan (head) memiliki nilai pengaruh langsung terbesar terhadap bobot biji $(1,205)$. Berdasarkan Gambar 5 indeks luas daun hanya memiliki nilai pengaruh yang sangat kecil terhadap bobot biji.

\section{KESIMPULAN}

Berdasarkan hasil dan pembahasan yang telah diuraikan maka dapat diambil simpulan bahwa:

a. Terdapat variasi beberapa variabel pengamatan dari 4 genotipe tanaman sorgum, serta terdapat hubungan antara beberapa variabel pengamatan.

b. Variabel pengamatan yang berupa bobot dompolan (head) dan bobot dompolan (head) tanpa biji menjadi variabel penting untuk menduga atau menghitung pembentukan bobot biji sorgum, berdasarkan uji korelasi dan sidik lintas.

c. Berdasarkan analisis ragam ILD tidak terdapat variasi, tetapi berdasarkan histogram genotipe Super-2 relatif tinggi $(2,39)$ dibandingkan dengan genotipe lainnya.

d. Pengukuran ILD dalam penelitian ini hanya mengukur pada saat daun bendera muncul dan tidak mewakili beberapa fase seperti fase pertumbuhan awal dan menjelang panen.
Andriani, A. dan M. Isnaini. 2006. Morfologi dan Fase Pertumbuhan Sorgum. Balai Penelitian Tanaman Serealia. $22 \mathrm{hlm}$.

Aqil, M., Zubachtirodin, dan C. Rapar. 2013. Deskripsi Varietas Unggul Jagung, Sorgum, dan Gandum, Edisi 2013. Iptek Tanaman Pangan 9 (1).

Afnita, Maria. 2017. Uji Korelasi dan Analisis Lintas Terhadap Karakter Komponen Pertumbuhan dan Karakter Hasil Tanaman Tomat. Jurnal Pertanian Konservasi Lahan Kering 2 (2): 33-35.

Arunah, U.L., Chiezey, U. F., Aliyu, L., \& Ahmed, A. 2015. Correlation and Path Analysis between Sorghum Yield to Growth and Yield Characters. Journal of Biology, Agriculture and Healthcare 5(19): 32-34.

Asner, G.P., Scourlock, J.M.O., \& Hicke, J.A., 2003. Global synthesis of Leaf Area Index Observations : Implications for Ecological and Remote Sensing Studies. Global \& Biogeography 12: 191-205.

Barclay, H.J. 1998. Conversion of Total Leaf Area to Projected Leaf Area in Lodgepole Pine and Douglas-Fir. Tree physiology 18: 185-193.

Du Plessis, J. 2008. Sorghum production. Republic of South Africa Department of Agriculture. Africa. $22 \mathrm{hlm}$.

Gusmayanti. Evi, T. Machida, and M. Yoshida. 2008. A Simple Model to Simulate Sago Palm Growth. Prosiding Semirata 2015 Bidang Teknologi Informasi dan Multi Disiplin 184-192. 
Ganghua, L., L. Xue, G. Wei, C. Yang, S. Wang, Q. Ling, X. Qin, Y. Ding. 2009. Comparison of yield components and plant type characteristic of highyield rice between Taoyuan, a 'special ecosite' and Nanjing, China. Field Crop 112: 214-221.

Hadi, M.S., M. Kamal dan K. Setiawan. 2016. Evaluasi Vegetatif dan Generatif beberapa Genotipe Sorgum [Sorghum bicolor (L.) Moench] di Lahan Kering. Prosiding Seminar Nasional PERAGI. Bogor, 27 April 2016: 1-6.

Harlan, J.R., and de Wet, J.M.J. 1972. A simplified classification of cultivated sorghum. Crop Science 12(2):172-176.

Hidayattullah. 2008. Path Coefficient Analysis Of Yield Component In Tomato (Lycopersicon sculentum). National Agricultural Research Center 40 (2): 627-635.

House, L.R. 1985. A guide to sorghum breeding. International Crops Research Institute for Semi-Arid Tropics. India. 206 hlm.

ICRISAT. 2002. Annual Report 2002 of Sorghum Research and Dissemination. International Crops Research Institute for the Semi-Arid Tropics.

I.K. Addai. 2015. Graphical Determination of Leaf Area Index and its Relationship with Growth and Yield Parameters of Sorghum (Sorghum bicolor L. Moench) as Affected by Fertilizer Application. Journal of Agronomy 14(4): 272-278.

Iriany M, R. N., dan Makkulawu, A. Takdir. 2013.Asal Usul dan Taksonomi
Tanaman Sorgum. Balai Penelitian Tanaman Serealia. 48-59.

Kementrian Pertanian. 2019. Statistik Lahan Tahun Pertanian 2014-2018. http://www.epublikasi.setjen.pertan ian.go.id. Diakses pada 13 maret 2020

Mahbub M.M., Rahman M.M., Hossain M.S., Mahmud F., Mir Kabir M.M. 2015. Genetic Variability, Correlation and Path Analysis for Yield and Yield Components in Soybean. American-Eurasian $J$. Agric. \& Environ. Sci. 15 (2): 231236.

A. M.A. Nasution. 2006. Analisis Korelasi Dan Sidik Lintas Antara Karakter Kualitatif Dan Kuantitatif Dengan Komponen Buah Pada Tanaman Nenas (Ananas Comosus (L). Merr.). Crop Agro 3(1): 8 hlm.

Rismunandar. 2006. Sorgum tanaman serba guna. Sinar Baru. Bandung. $71 \mathrm{hlm}$.

Salisbury, F. B. dan Cleon. W. Ross. 1995. Fisiologi Tumbuhan Jilid 3 Terjemahan. Institut Teknologi Bandung. 315 hlm.

Santoso S. B., Singgih S. 2014. Prospek Pengembangan Sorgum Manis Sebagai Bahan Baku Bioetanol. Balai Penelitian Tanaman Serealia. 16 hlm.

Setiawan, K., M. Kamal, M. S. Hadi, Sungkono dan I. Maulana. 2016. Keragaan Beberapa Kandidat Genotipe Sorgum Sebagai Penghasil Biomasa. Prosiding Seminar Nasional dan Kongres Perhimpunan Agronomi Indonesia2016. Bogor, 27 April 2016. 2-6. 
Singh RK, Chaudhary BD. 2010. Biometrical methods in quantitative genetics analysis. Kalyani Publisher 8 (12).

Siregar, Z., M. K. Bangun, dan R. I. M Damanik. 2016. Respons Pertumbuhan Beberapa Varietas Sorgum (Sorghum bicolor L.) Pada Tanah Salin dengan Pemberian Giberelin. Jurnal Agroteknologi 3(4): 3-5.

Strickland, J.D.H 1960. Measuring the production of marine phytoplankton. Fish. Res. Bull 122: 1-171.

Tira, E. W. 2017. Efektivitas Npk Organik Sebagai Pengganti NPK Anorganik Pada Budidaya Jagung Manis (Zea mays saccharata) di Tanah Regosol. Skripsi. Universitas Muhammadiyah Yogyakarta. Yogyakarta.

Vanderlip, R.L. 1993. How a grain sorghum plant develops. Kansas State University. $273 \mathrm{p}$.

Wang, Q., Adiku, S., Tenhunen, J., \& Granier , A., 2005. On the Relationship of NDVI with leaf Area Index in a Deciduous Forest Site. Remote sensing of environment 94 : 244-255.

Watson DJ. 1947. Comparative Physiological Studies in Growth of Field Crops: Variation in Net Assimilation Rate and Leaf Area between Species and Varieties and Within and between Years. Annals of Botany 11: 41-76. Di Dalam : Breda NJJ.2003. Ground Based Measurements of Leaf Area Index: a Review of Methods, Instruments and Current Controversies. Journal of Experimental Botany 54: 24032417
Yanuar, L. G. P. 2018. Penampilan Agronomi dan Hasil Etanol Beberapa Genotipe Sorgum (Sorghum Bicolor [L.] Moench) Pada Lahan dengan Penambahan Unsur Hara Mikro. Skripsi. Universitas Lampung. Lampung.

Yoshida, S., D. Forno, J.H. Cock, K.A. Gomez. 1976. Laboratory Manual for Physiological Studies of Rice. International Rice Research Institute, Manila, Philippines.

Yu, S-M., S-F. Lo, and T-H D. Ho. 2015. Source-Sink Communicatio: Regulated by Hormone, Nutrient, and Stress Cross-Signaling. Trends in Plant Science 20(12): 844-857.

Yusro. 2001. Pengelompokkan Varietas /Galur Sorgum (Sorghum Bicolor (L) Moench) Berdasarkan Ciri Morfologinya. Skripsi. Institut Pertanian Bogor.Bogor

Zakariyya Fakhrusy. 2018. Menimbang Indeks Luas Daun Sebagai Variabel Penting Pertumbuhan Tanaman Kakao. Pusat Penelitian Kopi dan Kakao Indonesia 28 (3): 8-12.

Zuidema, P.A.; P.A. Laffelaar; W. Gerritsma; L. Mommer \& N.P.R. Anten. (2005). A physiological production model for cocoa (Theobroma cacao): modelpresentation, validation and application.Agricultural system 84: 195225. 